\title{
Production of Edible Flowers in Florida ${ }^{1}$
}

\section{Caroline de Favari Tardivo and Geoffrey Meru ${ }^{2}$}

Edible flowers are an emerging category of food items. Contemporary chefs are showing a renewed interest in edible flowers and new cookbooks, along with popular articles in the United States highlight this interest (Bradley 2014; Bradshaw 2018; Breyer 2017; Sandborn 2015). Consumers appreciate edible flowers' flavor, color, and texture, and typically use them to garnish main dishes, entrees, desserts, salads, soups, and drinks (Barash 1993; Barash 1998a, b; Belsinger 1991; McVicar 1997; Rusnak 1999). Although their popularity in the US is recent, edible flowers have been part of European, East Indian, Middle Eastern, and Asian culinary traditions for at least a thousand years (Cichiwecz et al. 2004). There are more than 55 known genera of edible flowers (Badertscher and Newman 1996; Barash 1993; Belsinger 1991; Mcvicar 1997), some of which are commonly grown in Florida (Table 1).

In many edible flower varieties, flowers, flower buds, and leaves can be edible and contain high concentrations of bioactive metabolites, which provide medicinal benefits. In addition to being beautiful in any dish, edible flowers contain many minerals and nutrients such as vitamins A, C, riboflavin, and niacin (Arya et al. 2014; Petrova et al. 2016). They also possess anti-inflammatory, anti-mutagenic (neutralize mutation-inducing agents), anti-nociceptive (offer relief from nerve pain), and anti-tumorigenic (counteract the formation of tumors) properties (Ratnasooriya et al. 2005; Ukiya et al. 2002, 2006; Wongwattanasathien et al. 2010). Edible flowers are thus valuable because of their visual appeal, taste, nutritional content, and medicinal properties; therefore, they are considered "functional foods".

Small-scale growers have been successfully producing edible flowers in Florida. They target local outlets such as farmers' markets, grocery stores, and high-end restaurants and bars. The success of these growers is dependent upon producing sufficient edible flowers weekly, because the flowers generally have a limited shelf life (Hochmuth and Cantliffe 1990).

To maintain shelf life of edible flowers, they are packaged and distributed in small, rigid, and clear plastic containers (Whitman 1991) that are placed for sale in refrigerated displays. In general, refrigerated cases in grocery stores are maintained at $8^{\circ} \mathrm{C}$ and $9^{\circ} \mathrm{C}$ in the winter and summer, respectively (Le Blanc et al. 1996). Kelley et al. (2003) recommend a storage temperature of around to $10^{\circ} \mathrm{C}$ for some species of edible flowers to ensure a median one-week shelf life and maintain marketability.

Although growers and distributors are mainly concerned with lengthening the shelf life of edible flowers, they should also consider the food safety hazards of these products, which are intended to be eaten raw. Doyle and Erickson (2008) highlight the increasing concern about possible contamination of fresh produce. Therefore, producers should further scrutinize possible sources of contamination and consider implementing practices that reduce risks before the product reaches the consumer. When considering edible flowers and food safety, producers should advise

1. This document is HS1321, one of a series of the Horticultural Sciences Department, UF/IFAS Extension. Original publication date July 2018. Visit the EDIS website at http://edis.ifas.ufl.edu.

2. Caroline de Favari Tardivo, UF/IFAS Southwest Research and Education Center, Immokalee, FL 34142; and Geoffrey Mugambi Meru, assistant professor, Horticultural Sciences Department, UF/IFAS Tropical Research and Education Center, Homestead, FL 33031.

The Institute of Food and Agricultural Sciences (IFAS) is an Equal Opportunity Institution authorized to provide research, educational information and other services

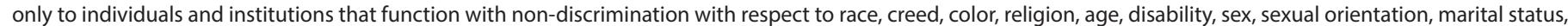

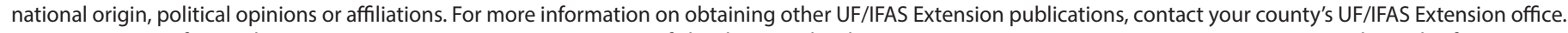
U.S. Department of Agriculture, UF/IFAS Extension Service, University of Florida, IFAS, Florida A \& M University Cooperative Extension Program, and Boards of County Commissioners Cooperating. Nick T. Place, dean for UF/IFAS Extension. 
consumers to store all fresh, edible flowers in a refrigerated space until ready to eat and, immediately prior to consumption, they should rinse in fresh water to remove potential contaminants (Wetzel et al. 2010) and also remove the styles and stamens from the flowers, as the pollen may cause an allergic reaction (Mlcek and Rop 2011). The production and commercialization of edible flowers can be successful with good food safety practices and solutions for the possible problems.

\section{References}

Arya, V., D. Kumar, and M. Gautam. 2014. "Phytopharmacological review on flowers: Source of inspiration for drug discovery." Biomedicine \& Preventive Nutr. 4: 45-51.

Badertscher, K. B., and S. E. Newman. 1996. Flowers. Ext. Bul. 7-237. Colorado State Univ.

Barash, C. W. 1993. Edible flowers: From garden to palate. Golden, Colo.: Fulcrum Publ.

Barash, C. W. 1998a. "The flavors of flowers." The Herb. Companion. 10: 32-37.

Barash, C. W. 1998b. "Please eat the flowers." Hort. 95 : 36-40.

Belsinger, S. 1991. Flowers in the kitchen: A bouquet of tasty recipes. Loveland, Colo.: Interweave Press.

Bradley, L. 2014. "Choosing and using edible flowers.” https://gardening.ces.ncsu.edu/2014/10/ choosing-and-using-edible-flowers/

Bradshaw, A. 2018. "Edible flowers list with edible flower names and pictures." https://commonsensehome.com/ edible-flowers/

Breyer, M. 2017. "42 flowers you can eat." https://www. treehugger.com/green-food/42-flowers-you-can-eat.html

Cichewicz, R. H., K. C. Lim, J. H. McKerrow, and M. G. Nair. 2004. "Kwanzoquinones A-G and other constituents of Hemerocallis fulva 'Kwanzo' roots and their activity against the human pathogenic trematode Schistosoma mansoni." Tetrahedron. 58: 8597-8606.

Doyle, M. P., and M. C. Erickson. 2008. "Summer meeting 2007 - the problems with fresh produce: an overview." J. Appl. Microbiol. 105: 317-330.
Hochmuth, R., and D. Cantliffe. 1990. Alternative Greenhouse Crops-Florida Greenhouse Vegetable Production Handbook, Vol 3. HS791. Gainesville: University of Florida Institute of Food and Agricultural Sciences. http://edis.ifas. ufl.edu/cv272.

LeBlanc, D.I., R. Stark, B. MacNeil, B. Goguen, C. Beraulieu. 1996. "Perishable food temperature in retail stores." New Development in Refrigeration for Food Safety and Quality Intl. Inst. Refrigeration Commission. 6: 42-57.

Kelley, K. M., A. C. Cameron, J. A. Biernbaum, and K. L. Poff. 2003. "Effect of storage temperature on the quality of edible flowers." Postharvest Biol. and Technol. 27: 341-344.

McVicar, J. 1992. Good enough to eat: Growing and cooking edible flowers. London: Kyle Cathie.

Mlcek J., and O. Rop. 2011. "Fresh edible flowers of ornamental plants - a new source of neutraceutical foods." Trends in Food Sci. \& Technol. 22: 561-569.

Petrova, I., N. Petkova, and I. Ivanov. 2016. "Five edible flowers-Valuable source of antioxidants in human nutrition." Intl. J. of Pharmacognosy and Phytochemical Res. 8: 604-610.

Ratnasooriya, W. D., S. A. Deraniyagala, S. D. N. K. Bathige, C. L. Goonasekara, and J. R. A. C. Jayakody. 2005. "Antinociceptive action of aqueous extract of the leaves of Ixora coccinea." Acta Biologica Hungarica. 56: 21-34.

Rusnak, J. 1999. "Edible flowers, fresh herbs, baby vegetables: still room for growth." Produce Business. 15: 33-37.

Sandborn, D. 2015. "Edible flowers: Adding color, flavor and fun to your dinner plate." http://msue.anr.msu.edu/ news/edible_flowers_adding_color_flavor_and_fun_to_ your_dinner_plate

Ukiya, M., T. Akihisa, H. Tokuda, H. Suzuki., T. Mukainaka, E. Ichiishi, and H. Nishino. 2002. "Constituents of compositae plants: III. Anti-tumor promoting effects and cytotoxic activity against human cancer cell lines of triterpene diols and triols from edible chrysanthemum flowers." Cancer Lett. 177: 7-12.

Wetzel, Kaedra., J. Lee, C. S. Lee, and M. Binkley. "Comparison of microbial diversity of edible flowers and basil grown with organic versus conventional methods." Canadian J. of Microbiol. 11: 943-951. 
Whitman, A. T. 1991. "Edible flowers and culinary herbs: new uses for traditional crops, new crops for traditional growers." Grower Talks. 54: 22-33.

Wongwattanasathien, O., K. Kangsadalampai, and L.

Tongyonk. 2010. "Antimutagenicity of some flowers grown in Thailand." Food and Chem. Toxicology. 48: 1045-1051. 
Table 1. Edible flowers grown in Florida. Common herbal medicinal uses, colors, varieties, and seed sources are listed.

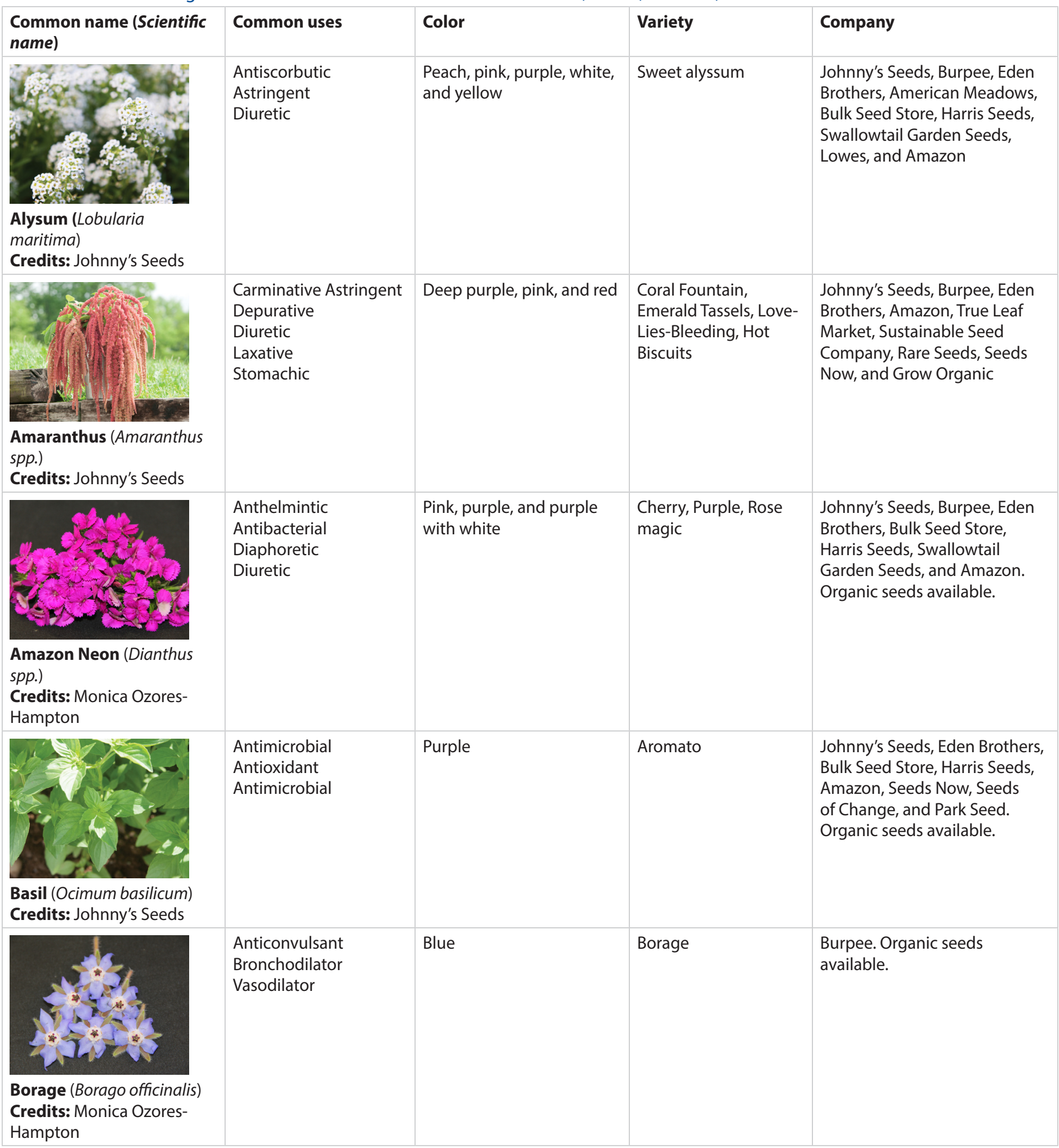




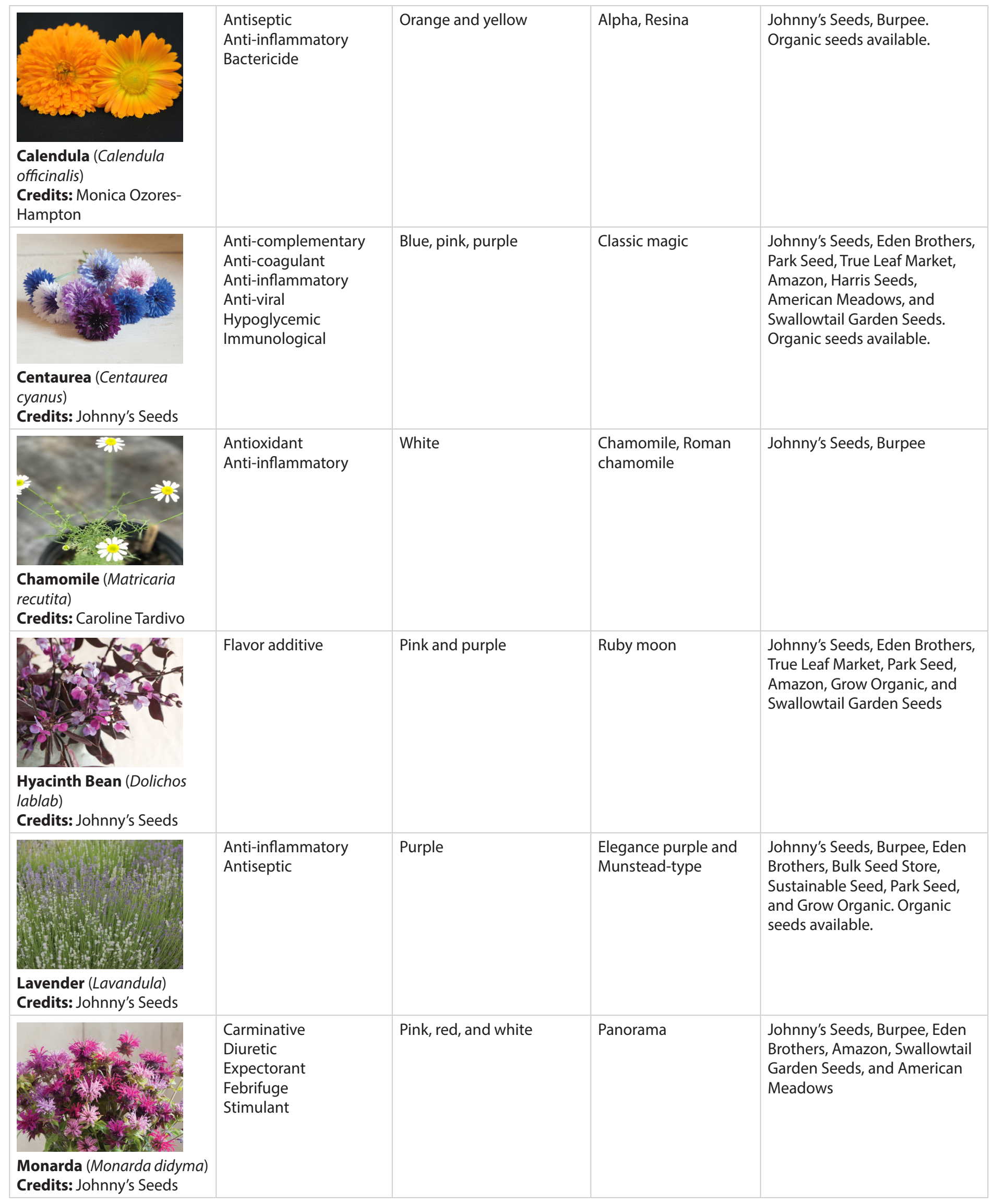




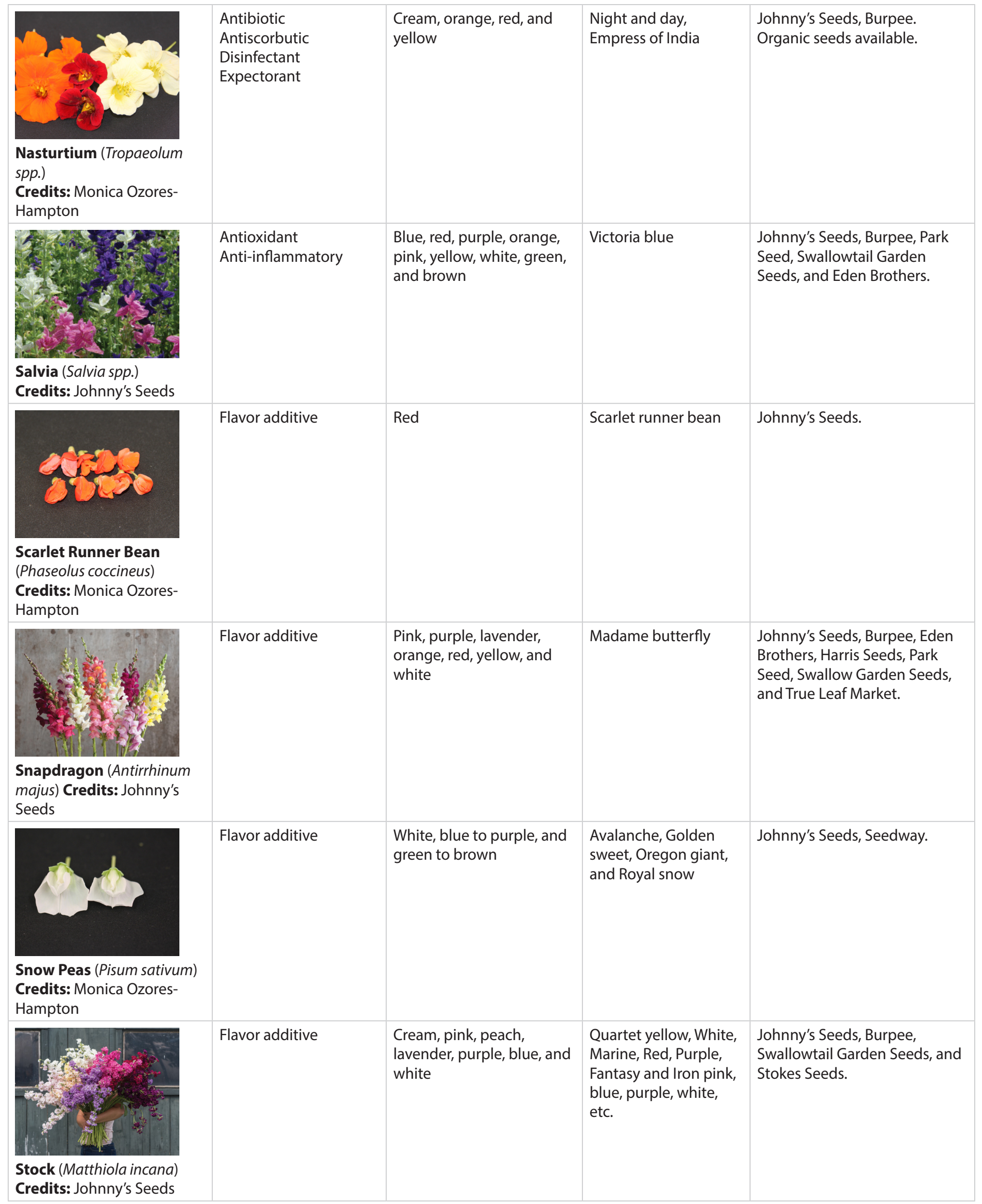




\begin{tabular}{|c|c|c|c|c|}
\hline & Flavor additive & $\begin{array}{l}\text { Yellow, blue, orange, and } \\
\text { violet }\end{array}$ & Tricolor, Helen mount & Johnny's Seeds, Burpee. \\
\hline $\begin{array}{l}\text { Viola (Viola spp.) } \\
\text { Credits: Monica Ozores- } \\
\text { Hampton }\end{array}$ & & & & \\
\hline
\end{tabular}

